\title{
A randomized controlled non-inferiority trial of primary care-based facilitated access to an alcohol reduction website (EFAR-FVG): preliminary results
}

\author{
Pierluigi Struzzo ${ }^{1,2^{*}}$, Roberto Della Vedova ${ }^{1}$, Donatella Ferrante ${ }^{2}$, Nicholas Freemantle ${ }^{3}$, Charilaos Lygidakis ${ }^{4}$, \\ Francesco Marcatto ${ }^{2}$, Emanuele Scafato ${ }^{5}$, Francesca Scafuri ${ }^{1}$, Costanza Tersar ${ }^{1}$, Paul Wallace ${ }^{6}$ \\ From INEBRIA 12th Congress, \\ Atlanda, GA, USA. 24-25 September 2015
}

\section{Background}

The effectiveness of brief interventions for risky drinkers by GPs is well documented [1]. However, implementation levels remain low. Facilitated access to an alcohol reduction website offers an alternative to standard faceto-face intervention, but it is unclear whether it is as effective [2]. This study evaluates whether online brief intervention, through GP facilitated access to an alcohol reduction website for risky drinkers, is not inferior to the face-to-face brief intervention conducted by GPs.

\section{Material and methods}

In a northern Italy region participating GPs actively encouraged all patients age 18 attending their practice, to access an online screening website based on AUDIT$\mathrm{C}$ [3]. Those screening positive underwent a baseline assessment with the AUDIT-10 [4] and EQ-5D [5] questionnaires and subsequently, were randomly assigned to receive either online counselling on the alcohol reduction website (intervention) or face-to-face intervention based on the brief motivational interview [6] by their GP (control). Follow-up took place at 3 and 12 months and the outcome was calculated on the basis of the proportion of risky drinkers in each group according to the AUDIT-10.

\section{Results}

More than $50 \%(n=3974)$ of the patients who received facilitated access logged-on to the website and completed the AUDIT-C. Just under 20\% $(\mathrm{n}=718)$ screened

\footnotetext{
* Correspondence: pierluigi.struzzo@phd.units.it

'Research \& innovation Area, Regional Centre for the Training in Primary Care, Monfalcone, Italy

Full list of author information is available at the end of the article
}

positive and $94 \%(n=674)$ of them completed the baseline questionnaires and were randomized. Of the 310 patients randomized to the experimental Internet intervention, $90 \%(n=278)$ logged-on to the site. Of the 364 patients of the control group, $72 \%$ (263) were seen by their GP. A follow-up rate of $94 \%$ was achieved at 3 months.

\section{Conclusions}

The offer of GP facilitated access to an alcohol reduction website appears to be an effective way of identifying risky drinkers and enabling them to receive brief intervention.

\section{Acknowledgements}

This work is jointly supported by the Italian Ministry of Health and by the regional school for the training in Primary Care of the Region Friuli-Venezia Giulia, Italy.

(Grant number: D25E12002900003). On behalf of the EFAR Study Group.

\section{Authors' details}

${ }^{1}$ Research \& innovation Area, Regional Centre for the Training in Primary Care, Monfalcone, Italy. ${ }^{2}$ University of Trieste, Department of Life Sciences, Italy. ${ }^{3}$ Department of Primary Care and Population Health, University College London, London, UK. ${ }^{4}$ Movimento Giotto, Bologna, Italy. ${ }^{5}$ stituto Superiore di Sanità, WHO Collaborating Centre for Research and Health Promotion on Alcohol and Alcohol-Related Health Problems, Osservatorio Nazionale Alcol, Centro Nazionale di Epidemiologia, Sorveglianza e Promozione della Salute, Rome, Italy. ${ }^{6}$ National Institute of Health Research Clinical Research Networks, University of Leeds, Leeds, UK.

\section{Published: 24 September 2015}

\section{References}

1. Kaner EFS, Dickinson HO, Beyer FR, et al: Effectiveness of brief alcohol interventions in primary care populations. Cochrane Database Syst Rev 2007, 2, doi: 10.1002/14651858.CD004148.pub3. 
2. Wallace P, Murray E, McCambridge J, et al: On-line randomized controlled trial of an Internet based psychologically enhanced intervention for people with hazardous alcohol consumption. PLOS ONE 2011, 6:e14740.

3. Struzzo P, De Faccio S, Moscatelli E: Identificazione precoce dei bevitori a rischio in Assistenza Primaria in Italia:o ed adattamento del questionario AUDIT al contesto italiano e verifica dell' efficacia d'uso dello shortAUDIT test nel contesto nazionale di assistenza primaria: uno studio di validazione interna. Boll delle Farmacodipendenze e Alcolismo 2006, XXIX:20-5.

4. Saunders JB, Aasland OG, Babor TF, et al: Development of the Alcohol Use Disorders Identification Test (AUDIT): WHO collaborative project on early detection of persons with harmful alcohol consumption. II. Addiction 1993, 88:791-804.

5. Rabin R, Charro F: EQ-5D: a measure of health status from the Euroqol group. Ann Med 2001, 33:337-43.

6. Miller WR, Rollnick S: II colloquio motivazionale. Preparare la persona al cambiamento. Erickson; 2004.

doi:10.1186/1940-0640-10-S2-029

Cite this article as: Struzzo et al:: A randomized controlled non-inferiority trial of primary care-based facilitated access to an alcohol reduction website (EFAR-FVG): preliminary results. Addiction Science \& Clinical Practice 2015 10(Suppl 2):O29.

\section{Submit your next manuscript to BioMed Central and take full advantage of:}

- Convenient online submission

- Thorough peer review

- No space constraints or color figure charges

- Immediate publication on acceptance

- Inclusion in PubMed, CAS, Scopus and Google Scholar

- Research which is freely available for redistribution

Submit your manuscript at www.biomedcentral.com/submit 